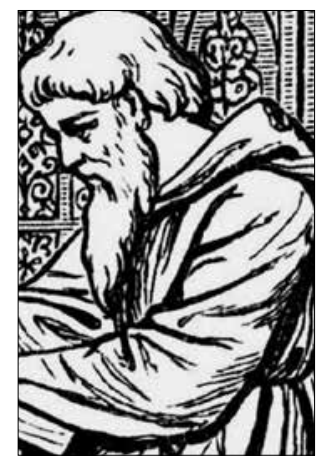

\title{
JONO SOLSBERIEČIO „POLIKRATIKAS” ARBA „APIE DVARIŠKIŲ PRAMOGAS IR FILOSOFŲ UŽSIĖMIMUS"
}

John of Salisbury's "Policraticus" or "On the Frivolities of Courtiers and the Footprints of Philosophers"

PIRMAS SKYRIUS

\section{KAS LABIAUSIAI KENKIA LAIMINGIESIEMS}

Iš visų dalyku, kurie kilniesiems vyrams kenkia, manau, nėra nieko pavojingesnio už tiesos matymą užtemdinančias lemties viliones, nes kai pasaulis jiems suneša savo turtus ir malonumus, kuriais skatina ir kursto godumą bei geidulingumą tiek, kad siela, pavergta įvairiausių išorinių malonumų apgaulès, atskirta pati nuo savęs išorinėmis gèrybemis ir stokojanti savo vidinio gèrio, atsiduoda įvairiems geiduliams. Mat dorybès pamotè - gera klotis - savo išrinktiesiems ploja, kad jiems pakenktu, i nelaimingą baigti juos sėkmès keliu atvestu ir pabaigoje visiškai sužlugdytų. Iš pradžių savo svečiams ji siūlo saldų vyną, o kai šie apsvaigsta, mirtinų nuodų arba dar ko nors blogesnio i jị i̇maišo. Kuo labiau ryškèja ju įvaizdis, tuo tirštesnès ūkanos dengia ju apstulbusias akis. Todèl tamsai didejjant, tiesos matymas silpsta, o pakirtus dorybès šaknį, želia ydų derlius, ir proto šviesai gęstant, žmogus nenumaldomai arteja prie nelaimių bedugnès. Taip protingas kūrinys sugyvulejja, taip Kūrejo atvaizdas panašumu i gyvuli iškreipiamas ${ }^{1}$, taip kilnus žmogus išsigimsta ir tuštybe ji padaro i save panašų tuo, kad besipuikuodamas jam skirta garbe, iš pasipūtimo praranda protą. Juk kas gali būti gèdingesnis už tą, kuris savęs pažinimą niekina, kuris Parkos ranka naudingam gyvenimui atmatuotą laiką - jo vienintelio už jokias 
palūkanas ir jokią atgailą neįmanoma susigrąžinti - gėdingai švaisto ir pelno Kūrèjo panieką. Kas gali būti gyvuliškesnis už ta, kuris dèl proto trūkumo ir pomėgio paskatos paniekinęs savo reikalus svetimais rūpinasi (Horatii 30 pr. Kr. b., Liber 2: 19), ir ne tik reikalais, bet ir svetimu laisvalaikiu mielai užsiima? Kas gali būti gyvuliškesnis už ta, kuris apleidęs savo pareigas vidurnaktį keliasi, kad pasinaudodamas šunų uosle, medžiotoju darbu, draugu pastangomis, aibės tarnų paslaugomis, švaistydamas laika, pinigus ir jẻgas, nuo aušros iki aušros su žvėrimis kariautų.

\section{ANTRAS SKYRIUS}

\section{KAS NETINKAMA}

Tikrai netinkama yra tai, kas ne iš prigimties arba pareigos kyla, nors vis dèlto kartais teisingai sakoma, kad teisingiau netinkamu vadinti tai, kas niekada niekam netinka. Tai, kas priklauso prigimčiai, visiškai vienodai visiems priklauso, o tai, kas priklauso pareigai, atskiriems asmenims priklauso. Tad vieno reikalauja pareiga, kito - prigimtis, nors pareiga reikalauja laikytis prigimties įstatymo, nes pasipriešinimas prigimties istatymui yra tẻvažudystės rūšis, ir šventvagystei prilygsta nepaklusimas tėvų i̇statymams, ir atsisakymui deramai gerbti visų mūsų motiną. Bet tai, ką protas iš deramų šaltinių priima, nėra be išlygų netinkama. Jeigu kartais išgaunamas kuklus malonumas arba nauda ir niekas žalos nepatiria, tai neprieštarauja pareigai arba prigimčiai; bet jeigu ką nors pažeidžia, tai yra tikrai ir be išlygu netinkama, ir niekam neleistina. Todèl tokių dalykų darymas visada yra arba klaida, arba nusikaltimas.

\section{TREČIAS SKYRIUS}

\section{PAREIGŲ PASKIRSTYMAS PAGAL SENOVĖS POLITINĘ SANTVARKĄ}

Pagonių filosofai teisingumu, kuris vadinamas politika, formuodami principus ir papročius, dèl kurių ir egzistuoja bei klesti žmonių respublika, nustatè, jog kiekvienas privalo pasitenkinti savo nuosavybe ir užsièmimu; taip pat, gyvenantiems mieste arba priemiestyje bei žemdirbiams arba kaimo gyventojams ju atskiras gyvenamąsias vietas ir darbą paskirste taip, kad kiekvienas atskirai ir visi kartu tarnautų bendrajam gèriui. Gamtos, darbo ir veiklos vaisių kiekvienas gaudavo pagal nuopelnus. Kiekvienam atskiram žmogui išlaikant gailestingos meilès jausma, niekas nesisavindavo to, kas priklause kitam. Geriausia vieta miesto centre buvo skiriama Areopagui ${ }^{3}$, kad isteigtas tinkamoje, atsižvelgiant i jo atliekamas pareigas, vietoje, jis savo isstatymais kitus užsiemmimus maitintų tarsi tam tikrais sveikatos ir gyvybės upeliais. Bet medžioklès menas arba profesija vargiai leidžiamas gyvenantiems priemiesčiuose, nes medžiotojai, kaip valstiečiai ir kiti kaimo vietovių gyventojai, yra labiau atskirti nuo kilmingesniu miesto gyventojų. Juk visiškai neteisinga, 
kad kilmingesnė prigimtis būtu pažeminta niekingais užsiėmimais, ir tie, kurių laukia sunkūs ir rimti darbai, vaikytųsi tuščiu malonumų. Tad medžioklè leistina kaip menas arba profesija, bet draustina kaip lengvabūdiška pramoga ir piktadarystė, ịstatymais baudžiant tuos, kurie ja neteisètai užsiima.

\section{KETVIRTAS SKYRIUS}

\section{APIE LEISTINĄ IR NELEISTINĄ MEDŽIOKLĘ, JOS RŪŠIS BEI DALYVIUS}

Jeigu tikètume istorikais, tai būtent Tẻbų piliečiai pirmieji nusprendè, kad visi gali ja užsiimti. Todèl visos gentys juos įtare esant susitepusius tẻvažudyste, šlykščia kraujomaiša, ženklų klastojimu ir melagingomis priesaikomis. Visus šiuos pasibjaurètinus dalykus ju sumanytojai, o gal geriau sakyti - piktadariai, i pirmąsias nuostatas įtraukè, kurias vèliau Frygams, išlepusiai ir bailiai, lengvabūdiškai ir gėdos neturinčiai genčiai, perdavė. Iš tėbiečių šaiposi atẻniečiai ir lakedemoniečiai, rimtesni žmonès, kurių istoriniai žygiai, prigimtis ir papročiai apgaubti įvairiais paslapties šydais, bet šaiposi taip, kad blogybių išjuoka būtų naudinga arba pasakojimo poetiškumas teiktų malonumą. Todèl jie pasakoja, kad erelis Dardanijo medžiotoją pagrobẻ pokyliui, po kurio vyko smerktinos ir nenatūralios glamonės (Ovidijus 1979: 264 [145-160] $)^{4}$. Be abejo, tai logiška, nes kaip lengvabūdiškumas būdingas paukščiui, taip blaivumui aklas malonumu troškimas nesigedija atsiduoti bet kokiai aistrai.

Tẻbiečiu vadas, kai netyčia pasiklydo, išvydo nuogumą tos, kuri visada miškuose gyveno, ir buvo paverstas žvèrimi, bet žmogiškai jaučiančiu. Ir kai jis, jau turẻdamas elnio pavidala, bandè savo šunis balsu sulaikyti, buvo jų nasrais sudraskytas, nes taip gèdingai daryti jie buvo ipratinti (ten pat: 69-73 [III, 135-250]). Gal todèl medžiotoju globejja buvo išrinkta deivè, nes tokia ydinga veikla dievai nenorejo susitepti. Venera, pati būdama ištverminga medžiotoja, šerno iltimis nužudytą Adoni aprauda (ten pat: 276-277 [X, 525-555]; 281-282 [X, 710-735]). Maronas, noredamas išjuokti kilnų Kartaginos svetinguma, nežino, kaip patenkinti įsimylejejlius, kaip tik suteikdamas jiems progą medžioklëje, miško oloje nuo kitu atsiskyrus (Vergilijus 1989: 69 [IV, 155-175]).

Galbūt taip yra todèl, kad nešvari begėdystės sąžinè nekenčia šviesos, o teisèta meilè, priešingai, džiaugiasi savo vestuvių šviesiaisiais deglais apšviesta.

Ar gali man paminèti nors vieną garsų vyra, kuris medžioklès malonumams būtų labai atsidavęs? Pergalingasis Alkidas, nors variakoja elnę pašovè ir Erimanto jis apramino girias... (ten pat: 127 [VI, 802-803]), padare tai ne savo malonumo geismą tenkindamas, o bendrojo labo siekdamas. Kalidonijos niokotoją šerną Meleagras nudejjo ne sau malonumo ieškodamas, bet siekdamas išlaisvinti kraštą nuo priešo (Ovidijus 1979: 212 [VIII, 414-429]). Romėnu giminès pradininkas sumedžiojo elnius ne savo malonumui, bet tam, kad sau ir savo bendražygiams parūpintų maisto 
(Vergilijus 1989: 10 [I, 185-194]). Vyru darbai vertinami pagal rezultatus ir tikslus. Juk dèl kilnaus tikslo atliktas darbas yra puošmena.

Tačiau jokio pavojaus nekyla tam, kuris žmonių ir šunų armiją surenka, kad ne tiek savo, kiek svetima drąsa su žvėrimis kariautų. Gal nelaimingą žvėrelį, baikštų zuikeli jis ruošiasi sumedžioti. O jeigu stambesnis grobis - elnias ar galbūt šernas bus sumedžiotas, tai kils didžiulis medžiotojų džiaugsmo triukšmas. Nužudyto žvėries galva ir kiti iprasti grobio atributai nugalètojams bus pateikti taip, tarsi švenčiant Kapadokijos karaliaus paėmimą i nelaisvę, jeigu spręstume pagal nugalètoją šlovinančius trimitų ir švilpynių garsus. Patelę ar kitą ne tokị kilnų grobi sumedžiojus daugiau apgaule negu drąsa, triukšmas nekyla. Jei sumedžiojama tik stirna ar kiškis, manoma, kad toks grobis triumfo nevertas. Be to, nuo aštuntojo Ožiaragio laipsnio iki pat Dvynių švilpynių ir trimitų garsai nutyla, nebent sumedžiojamas vilkas arba kitas grèsmingesnis priešas, galbūt liūtas, tigras arba pantera, bet, ačiū Dievui, kad tokia garbè mums retai atitenka. Vis dèlto didžioji metų dalis skiriama įvairioms medžioklèms.

Albanai Azijoje ${ }^{6}$ turi už liūtus stipresnius šunis. Jų ir savo išradingumo padedami jie liūtus medžioja tarsi taikius gyvūnus. Iš tiesų nèra jokio už tuos šunis stipresnio ir drąsesnio laukinio gyvūno. Juos iš Italijos ị Aziją atgabeno Heraklis, nugalèjęs trigalvị baisūną Gerioną (Hesiodas 2002: 77 [981]), ir išmokẻ juos pulti liūtus. Toks budelio darbas reikalauja meno, ir jie tą meną darbais savo rodo. Jeigu tau atsitiktų dalyvauti šventose medžiotoju apeigose, matytum, kaip tiesiog skrajoja, pjaudamas mésa, peilis (Juvenalis 1983: 36-37 [121-122]), trumpasis durklas arba atšipęs kardas. Tačiau būk atsargus, kad kalbėdamas kokiu nors neatsargiu žodžiu jų neizžeistum, nes tave jie arba primuš, arba būsi paniekintas kaip nesuprantantis bendrojo gèrio, jeigu ju išmonès nepripažinsi. Šitie menai mūsų dienomis yra palaidas kilmingujju užsièmimas. Jie laikomi pirmaisiais dorybès elementais, jais grindžiamas trumpiausias kelias iš palaimos ị aukščiausią laimę, i tiksla, kurio mūsų protéviai mokè siekti ne kuo nors kitu, o tik sunkiu dorybingu darbu iš lèto kopiant i viršų.

Galai juokiasi iš Emilijos ir Ligurijos gyventoju sakydami, kad šie testamentus surašę ir kaimynus sukvietę maldavo ginti juos ginklais, jeigu prie ju teritorijos ribų prisiartintų karingai nusiteikęs vėžlys. Tai turëjo reikšti, kad joks užpuolimas jų neužklups nepasiruošusių. Ir kaip mūsų žmonės pašaipos išvengia, kai daug didesni triukšma, rūpestị ir didžiules lèšas mano esant tinkama skirti žvèrims iškilmingai paskelbtam karui? Bet jie mažiau persekioja tuos žvėris, kurie žmonių giminei iš tiesų yra priešiškeni ir žalingesni. Vikas, lapè, meška ir kiti, dar plěšresni žvėrys paliekami ramybejje tuo metu, kai kiti žudomi, ir dažnai jie, net medžiotojams matant, nebijo daryti pikta.

Pasakojama, kad Hanibalas įsakė nužudyti romėna, kuris jo paties isakymu dvikovoje vienas prieš vieną užmušè drambli (Plinius AD77: Liber 8 [VII, 18]). Hanibalas pasakè, jog tas, kuri galima priversti kovoti su žvėrimis, nevertas gyventi. Nors veikiau jis tai padare iš pavydo, nenoro belaisviui suteikti neregètą garbę ir 
triumfą ir tuo užtraukti negarbę gyvuliams, kurių galia tautas baimėje laikè. Tai kaip gali būti vertas gyventi tas, kurio niekas gyvenime nedomina, išskyrus beprasmi ir žiaurų karą su žvėrimis?

O tie, kuriuos džiugina ta medžioklès rūšis, kurios metu paukščius paukščiai persekioja, - jei manai, kad toki paukščiu gaudymo būdą galima laikyti medžioklès rūšimi, - tikrai kenčia nuo palaidos, lengvabūdiškos beprotybès. Medžioklè žemès paviršiuje, palyginti su medžiokle ore, yra rimtesnis ir pelningesnis užsièmimas. Oro medžioklès mėgèjai skelbia, jog senovės istorikai jos išradëju laiko esant Odisëja, kuris, sugriovus Troja pirmas graikams parode plešriuosius paukščius, tikrai žiūrovu nuostabai ir padèkos vertam malonumui išmokytus jiems artimas gimines žudyti. Iš tiesų jie sau išrinko didelį užtarèją kuris dangio žmoniu miestus aplanke ir ju papročius matè (Homeras 1997: 5 [3]), kurio apdairumo jokia klasta negalëjo pranokti, iš kurio pinkliu joks priešas neištrūko sveikas, kurio neginkluoti bendražygiai Graikijos šlovę iškèlè aukščiau negu ginkluotos tūkstančio laivų igulos. Bet ir jis pirmenybę atidavè Kirkei, kuri jo bendražygiu žmogiškas sielas dainomis ir gèrimais, užkalbëjimais ir meilumu pakeitè ir savo valiai pajungẻ kaip panorejusi. Todèl, kai graikams buvo paduotas įtartinas, geidulingumą žadinantis gėrimas, apdairusis Odisėjas, jo paragavęs, atsisakė gerti, kad nelemtos paleistuvės valdžion nepatektu ir nebūtu priverstas kvailai gyventi. Juk kaip tikra išmintis žino, kaip visais daiktais teisingai naudotis, taip apdairusis vyras numatė darbų apimtis ir galimas klaidas. Kai skaisčioji Penelopè ir mylimas Telemachas jo neatpažino sugrižus, jis sumanė, kaip Graikijai atlyginti daugybės savo bendražygių klajonėse praradimą.

Nuostabi ištikimybė šuns, kuris vienintelis iš visos šeimos po ištisų dvidešimties išsiskyrimo metų šeimininką atpažino ir net džiaugsmingai sugrižusi pasitiko. Bet juo reikia žavètis santūriai, kad jo šlovė medžiokliniams šunims netyčia neatitektų. Tačiau aš žinau, kad savo Telemachui jis patare gyventi neužsiimant medžiokle, sakydamas, kad vien tik tiems skirta naujos medžioklès paguoda, kurie, Trojos kare tėvus praradę, žalą patyrè. Todèl darau išvada, kad bergždžias yra tas menas, kuri nuo savo vienatinio sūnaus tas toks apdairus vyras stengèsi atskirti.

Iš viso to kartu su manim daryk išvada, kad prastesnioji lytis paukščių medžioklëje yra stipresnè. Dẻl to galètum kaltinti prigimti, nebent žinotum, kad prastesnieji visada labiau linkę plèšikauti. Medžioklè iš tiesu yra bergždžias ir varginantis užsièmimas, kurio sẻkmẻ niekada neatlygina išlaidų. Gali būti, jog dauguma medžiokle užsiima, kad ja prisidengę savo išlaidas sumažintu, namuose rečiau, dažniau prie svetimo stalo valgytų, kai po miškais apaugusius kalnus ir aplink ežerus bastosi, prastais apsivilkę drabužiais, pasitenkina paprasčiausiu maistu, tuo metu ju namiškiams ir tarnams, kuriuos alkis kankina, prasta apranga žemina, ir pernelyg sunkus darbas sekina, kaip paguodą jie gali pasiūlyti smagumo, arba veikiau tuštybès, vaizdą.

Pirmają žalą Atėnai patyrẻ būtent tada, kai atšaukẻ medžioklę draudžianti i̊sakymą ir visu rūšiu medžioklę oficialiai paskelbė leistiną. Pasakojama, kad Man- 
tujos žiniuonis ${ }^{7}$ Marcelo, entuziastingai užsièmusio paukščių naikinimu, paklausè, ar šis pageidautų, kad paukščiai būtų išmokyti gaudyti paukščius ar kad musès būtų išmokytos muses naikinti. O kai šis, prašydamas patarimo, tą pati klausimą pateikė savo dẻdei Augustui, šis patarè pasirinkti muses, kad jos iš Neapolio muses išvarytų ir miestą nuo nepakenčiamų kenkèjų išvaduotų. Toks pasirinkimas iš tiesų parodo, kad pavienio asmens malonumas turi būti aukojamas daugumos naudai.

Jeigu apskritai galima tikèti graikais, tai kentauro Chirono oloje Achilas iš pradžių buvo mokomas groti lyra ir kitara, o vèliau, iš jos i mišką išvestas, žudydamas ir skersdamas žvėris bei ipratęs pasitenkinti prastu maistu, prarado pagarbą gamtai bei mirties baimę paniekino. Ar nepasakojama, kad ir Bachas turëjo tą patị auklètoją? Žinoma, kad tie, kurie tokiais norais ir polinkiais gyvena, yra pusiau žvėrys, didesnę žmoniškumo dali paniekinę elgiasi kaip pabaisos. Nuo lengvabūdiškumo prie palaidumo, nuo palaidumo prie geismingumo, o kai užkietėja - prie bet kurios neleistinos begėdystės pereina. Poilsio jiems reikia po darbų. Po įtemptų pastangu pasismaginimas būna malonesnis tiems, kurie save plèšikavimais labai išsekino. Iki šiol medžiotojai kentauro auklëjimu dvokia. Retai tarp jų sutiksi kuklų arba rimtą vyra, retai santūrų ir, manau, niekada supratingą. Juk Chirono namuose jie buvo mokomi būti kaip tik tokie. Juk būtent dèl to patariama vengti kentaurų pokylių (Ovidijus 1979: 320 [XII, 210 ir toliau]), iš kurių niekas negrižta nesužeistas.

Jeigu neimanoma tikèti tomis istorijomis, kurias poetai savo vaizduotès pramanais iškraipo, tai būtina tikèti tomis, kurios, Dievo ranka parašytos, visų tautų pripažintos teisingomis. Pirmiausia istorija apie Nimroda, Viešpaties malone galingą medžiotoją ${ }^{8}$. Neabejok, kad jis buvo nedoras, nes visi mokyti žmonès ji dejl šiurkštumo smerkè. Pasakojama, kad jis pasikèle i tokias beprotybės aukštumas, kad nepabijojęs paniekinti gamtos įstatymo, vergais padare tuos, kurie iš prigimties savo kilme ir padètimi buvo jam lygūs. Todèl tironijai, kurios aukščiausias laipsnis yra nepagarba Kūrèjui, kito nerado pradininko, išskyrus medžiotoja kuris žudydamas žvėris ir kraujo klane besivoliodamas išmoko niekinti Dievą. Jis buvo pirmasis galiūnas žemèje, bet yra parašyta, jog netikejjo, kad buvo Viešpaties malone galingas (Pr 10, 9-10). Babilonas buvo pradžia jo viešpatavimo, kuri jis išplète i Šinaro žemę, ir tada, kai visi žmonès žemèje kalbejjo vienomis lūpomis ir viena kalba, ten ị dangu iškilo Babelio bokštas, pastatytas ne iš akmenų, o iš bitumu dengtų plytų. Jo pamatuose nebuvo akmens, kurio vienintelio tvirtumu remiasi kiekvieno pastato Viešpatyje tvarumas.

Tačiau begėdiškas akiplèšiškumas, sunaikindamas vienybę, sunaikino kalbos vienovę ir pirmiausia sukèle sumaišti, kuri pasireiškè tuo, kad save jie šlovino labiau negu Viešpati. Iš čia kilo šis priežodis: Stiprus kaip Nimrodas Viešpaties akivaizdoje, galbūt todèl, kad pasireiškè tokia jo puikybè, jog net nesena potvynio bausmè jo nepamokè, kad Viešpaties akivaizdoje nedera savimi didžiuotis ir iš žmonių sau reikalauti tik Dievui deramo paklusnumo, kuri atkakliai savinosi, kadangi žinoma, jog potvynis įvyko prieš kalbų sumaišymą. Iš tiesų Babilonas iš savo auksinès taurès nugirdè visą pasaulį ${ }^{9}$, ir prieš aukščiau stovinčią Jeruzalę ${ }^{10}$ pastatè 
neabejotinai pražǔčiai skirtą stovyklą, kurios visi kariai yra prakeikti amžinuoju palaimintuju prakeiksmu.

Esavas irgi mėgo medžioklę ir tuo nusipelnè, kad apgaulès keliu netektu tėvo palaiminimo ${ }^{11}$. Miške jis taip išalko, kad nesuvaldomo alkio genamas už saują menkaverčių lęšiu savo pirmagimystę pardavè ir paveldimos vergovés jungą savo palikuoniams paliko, kad jaunesniojo brolio, kuris namuose leisdavo laiką, valdžiai savo sprandus palenktu. Esavo rankos pasišiaušusiais plaukais buvo tankiai apaugusios ir, pratęs prie klajonių miške, jis nemokejo mandagiai elgtis ir prašmatniuosius savo apdarus kartu su geromis manieromis palikdavo namuose, nes nuolatos būdavo užsièmęs medžiokle. Jis troško savo brolio kraujo, tačiau, iš anksto palenktas jo dovanomis, leidosi jo įkalbinejjamas, nors žinojo, kad Dievo malonė jam suteikẻ pirmenybę tèviškojo palaiminimo reikale.

Jie giriasi, kad medžioklès paukščiais pradininkas buvo Makabejus, bet jis didesniais dalykais užsièmęs, kaip manoma, prakilniau gyveno: sėkmingai kariavo, broliams grąžino laisvę, patobulino įstatymus, pataisė papročius, išvale šventąsias vietas, šventyklos fasadą išpuošè aukso vainikais, nes tikèjo, kad iš jos kyla visos jo pergalès, ir nè i̇ vieną jo veiksmą slapčia neisslinko joks savanaudiškas malonumas ir nepareikalavo savo dalies (Lucanus 1962: 86 [391]). Mūšio lauke kritęs už savo brolius, jiems kaip paveldą paliko teisètą karą.

$\mathrm{Tu}$, kuriam nuo pat pirmuju gyvenimo metu gamta skyrẻ vadovautis protu, pradèk nuo patriarchų duoto įstatymo, pereik prie karo vadų, toliau prie teisèjų ir karalių, peržvelk pranašu gretas, ištirk dievobaimingos liaudies pareigas ir siekius; ar senuju isstatymu eilèje perskaitysi tuos, kuriuos išleido medžiotojai? Rodos tik edomitai ${ }^{12}$, išmaelitai ir Viešpaties nepažinusios gentys. Kur yra tie, klausia pranašas (arba, jeigu nori, pranašo ikkvejptas raštininkas), kurie žaidè su padangiu paukščiais? $($ Bar 3,17$)$ Ir tarsi turẻdamas omeny tuos, kurių gyvenimas yra žaidimas, prisiminė tuos, kurie išnyko su savo paukščiais ir pasmerkti nugarmejjo i pragarą. Paklausk savo tèvų ir jie tau pacituos tavo protėvius, ir pasakys, kad niekada nėra skaitę apie medžiotoją kuris būtu tapęs šventuoju.

O jeigu norètum medžiotoju vardą pagirti remdamasis pranašu pažadu, kad Dievas pasiųs medžiotojus, kurie klaidatikius išmedžios ir žemumose, ir aukštumose ${ }^{13}$, turètum žinoti, kad ruošiesi garsinti gyvulišką gyvenimo būda, nes medžiotoju tuštybè neturi būti giriama.

Ir, žinoma, tavęs neturi paveikti dievobaimingame, nors ir nekanoniniame, Šventajame rašte aprašytas ir tavo paties pateiktas atvejis, kai kankinį Placidą dar žinomą Eustachijaus vardu, medžiojanti Dievas aplankè, nes tas atvejis nieko per daug nekeičia, nebent norètum girti bažnyčios persekiotojų siautèjimą remdamasis tuo, kad iš ju tarpo Paulius buvo pašauktas apaštalauti ir padarytas vienu šlovingiausių evangelijos skelbejjų.

Buvo medžioklei atsidèje garsūs vyrai, Aleksandras ar galbūt Cezaris, bet ar rasi tarp jų filosofą arba tą kurị žmonės manytų išminčiumi esant? Ar rasi Sokrata, 
Platoną, Aristotelį, Seneka, Soraną ${ }^{14}$ arba tą, kuris savo išmintimi ir dora būtu nustelbęs visus ne tik savo miesto, bet ir pasaulio stebuklus, kaip tai padare Architas iš Tarento? ${ }^{15}$

Bet grižkime prie mūsiškiu, prie tų, kurie mokymo teisingumu, pavyzdžio dorumu ir tikëjimo galia pasižymëjo. Ar tarp Augustinu, Jeronimų, Laurenciju, Vincentiju, galiausiai visoje Bažnyčios Tẻvų bendruomenèje rasi bent viena, kuri būtų persekiojusi medžioklès manija? Net ir mūsų laikais skaudžiais pavyzdžiais esame mokomi nuo tokios neramios veiklos susilaikyti, kai mūsų didikus medžioklèje pražudo tikri ivvairūs dieviško pasipiktinimo daromi stebuklai: tie, kurie gyvena kaip gyvuliai, neretai susilaukia gyvuliškos šio gyvenimo pabaigos. Dievo ranka nepasigaili net ir pačių karalių ir už jų piktadarybes skaudžiai baudžia. Jų vardų ir bausmès pavyzdžių neminime ne todèl, kad ju trūktų, bet veikiau todèl, kad dèl ju gausos sunku pasirinkti, ir dèl to, kad nesukeltume pernelyg didelio sielos skausmo aitrindami dar šviežias, gilias žaizdas. Net ir namuose turime pavyzdžių daugiau, negu reikia.

O kai kurie šitos tuštybès įkvẻpimo skatinami puola į tokią beprotybę, kad tampa prigimties priešais. Jie pamiršta savo padètĭ, paniekina dieviškuosius sprendimus, kai žvėriu gynimui pajungia Dievo paveikslą ir šitaip ji pažemina. Ir nebijo už žvėreli sunaikinti žmogu, kuri Dievo vienatinis savo krauju atpirko. Žvėris, kurie yra gamtos nuosavybė ir pagal isstatymą priklauso tiems, kurie juos paima, žmogiškas akiplèšiškumas drịsta savintis net akivaizdoje Dievo, kuris tą patị ịstatymą visiems davè ir kuriuo tarsi viską gaubiančiu tinklu apdengè. Labiau stebina tai, kad pagal ju i̇sakymus kilpu statymas paukščiams, žabangų rengimas žvėrims, jų viliojimas masalais ir švilpynėmis, taip pat gaudymas bet kokiais kitokiais spąstais dažnai tampa nusikaltimu, už kurị baudžiama arba turto, arba kūno narių ir gyvybės atėmimu. Kalbama, jog dangaus paukščiai ir jūros žuvys yra bendra visų nuosavybė, kurią tačiau medžiotojai [karaliaus vardu] savinasi visur, kur tik panori. Netiesk $\mathfrak{i}$ juos savo rankos, nemėgink jų liesti, kad ir tu, apkaltintas jo didenybės įžeidimu, netaptum medžiotoju grobiu.

Žemdirbiai neįleidžiami i savo laukus, kad tik žvèrys galètų laisvai klajoti. Kad turètų daugiau ganyklų, iš žemdirbių atimama sẻjai tinkama žemė, bendru ganyklų plotai, o žydinčiose pievose neleidžiama statyti avilių ir net pačioms bitèms trukdoma laisvai skrajoti. Gerai sakai, kad visa savo galia jie negali išbaidyti gylių ir kitų kenkejjų, kurie ne žvèris, o galingụjų malonumus gadina, kai net uodas, keršydamas žmogui, savo aštru geluonį naudoja tiesiai prieš žvėris.

Tad jeigu gyventum čia, tai būtum priverstas metai iš metu išpirkti arba prarasti savo pasėlius. Pasirink kurią tik nori iš piliečiu lygybès teisių, vis tiek tau neišvengiamai grès arba turto, arba gyvybès netektis. Jeigu kas nors iš medžiotojų kirstų tavo žemių ribas, tai visa, ką namuose turi, nedelsdamas pagarbiai jam pateik, o jeigu ko nors namuose neturi, bet kaimynas turi, tai jo naudojimuisi nupirk, kad jis, remdamasis edikto galia, prieš tavo valią tavo nuosavybės neatimtų ir, apkaltinęs nepagarba bei panieka, nepatrauktų tavęs ị šimtinès arba provincijos vietininko, 
arba keliaujančio karaliaus teisėjo, arba net galbūt i paties karaliaus teismą atsakyti i kaltinimą valstybès išdavyste. Juk valstybės iždas turtėja, kai dẻl kurios nors priežasties priverčia šeimą daryti išlaidas.

Kad neatrodytu, jog medžioklę ir kitas tuščias dvariškiu pramogas savo stiliumi užsipuolu neapykantos, o ne samprotavimo vedamas, lengvai ir laisvai sutinku, kad ją reikia priskirti prie gėriui ir blogiui abejingu dalyku, nebent jos teikiamas besaikis malonumas vyrišką sielą silpnintų ir proto pamatus griautų. Tačiau dẻl to reikia kaltinti ne ją. Juk kai vynas nugirdo, kaltas ne jis, o geriantysis. Ir kai senis mąsto vaikiškai, dažniausiai kaltas ne jo amžius, bet ydos. Vadinasi, medžioklè irgi gali būti naudinga ir garbinga, jeigu atsižvelgiama i̇ vieta, laiką būda, asmenị ir tikslą. Juk asmuo puošia veikla, kai vykdo savo pareigas ir nesikèsina į svetimas. Ir niekas jam netinka labiau negu tai, kas labiausiai dera jo pareigai. Juk Etikas, atskiriems asmenims priskirdamas deramus dalykus, aiškiai sako: Kiekvienam labiausiai tinka tai, kas labiausiai jo (Ciceronis 44 pr. Kr. a.: Liber 131 ).

Tad ką bendro tu ir aš turime su medžiokle? Juk gèdingiausia apleisti savą ir uoliai užsiimti svetima veikla. Ką bendro su paprasta ir gal net su valstietiška veikla gali turèti tas, kuris valstybės valdymo ženklais paženklintas? O kad liaudis eitu paskui vadova, mokytojas skleistų moksla, teisẻjas persekiotu nusikaltẻlius, darbštieji būtų valdžios apdovanojami, paprasti žmonès užsiimtu paprastais dalykais, kilmingesnieji - garbingesniais, o prasti dalykai būtų skirti vergu padètyje esantiems.

Juk tai, kas garbingiems bjauru (ar Sëjui, ar Ticijui), tinka mūsu Krispui.

(Juvenalis 1983: 28 [IV, 13-14])

Mat nors kūnas turi daug organu, tačiau visi jie skirti ne tam pačiam veiksmui, bet kiekvienas atlieka tik jam vienam skirtas pareigas. Tai kodèl tu, kuris medžiotojui neatiduodi savujuu, saviniesi jo pareigas? Ar nieko gèdinga nematytum, jeigu medžiotojas kèsintųsi i karaliaus arba popiežiaus pareigas? Tai tikrai dar gédingiau būtu, jeigu kuris nors iš šių didžiūnų nusižemintų iki žiauraus ir kruvino medžiotojo darbo. Ir iš tiesu gèrio meilè visada siekia kilti i viršų ir, priešingai, ydos skatulys pats savaime smukdo žemyn.

Tikslas taip pat gali išaukštinti veikla, kai ji grindžiama arba būtinybe, arba naudos didinimu, arba dorybingumo sklaida, nes siekis turi galią pakeisti visą veiklos pamatą ${ }^{16}$. Mat, pasak filosofo, tavo siekis tavo vardu tavo veiklą ženklina. Todèl nèra nieko smerktino, kad tèvo pavedimu Esavas išèjo medžioti siekdamas pasotinti tèvo alkị ir paklusnumu užsitarnauti pažadètą brangujị palaiminimąa ${ }^{17}$. Mat jeigu to padaryti nenusikalstant nebūtu galima, tai toks svarbus patriarchas jokiu būtu nebūtų sūnaus siuntęs atlikti tokio darbo ir palaiminimo malone nebūtų žadèjęs už jo atlikimą skirti tautų valdovu. Bet galbūt Esavas iš ipratimo ir dèl nesaikingo pomėgio tam darbui skyrẻ daugiau negu leistina laiko ir tuo uždelsimu atsidūré pavojuje. Niekas nekaltinamas už tai, kad neišvengiamos būtinybès priverstas teisètomis pastangomis palaiko gyvybę. 
Kurie vengia pasyvaus poilsio ir sunkiais pratimais pratina savo kūną prie darbo, kurie vengia ydingo kūno nepaslankumo ir visuose reikaluose išsaugo asmens oruma, tie niekada nepatiria teisingo priekaišto geluonies dūrių. Juk veikla ne pati savaime, o tik dèl tikslo tampa nusikalstama. Ir jokia iš malonumo kylanti dorybė nepateisina veiklos, nes malonumas yra dorybès patėvis. Aš kalbu ne apie tą malonuma, kuris kyla iš ramybès, kantrybės, geranoriškumo, pakantumo ir džiaugsmo Šventojoje dvasioje ${ }^{18}$, o apie tą kuris yra puotavimo, gèrimo, pokyliu, dainavimo ir šokių, varžybų prabanga, paleistuvavimo ir įvairių nešvarių dalykų draugas, kuris net kiečiausias sielas minkština ir kažkokia prigimties apgaule vyrus daro ištižusius ir pagedusius labiau negu moterys.

Laikas taip pat medžioklès kaltę mažina ar net panaikina. Bet dažniausiai tik tais atvejais, kai jis palankus atlikejjams. Todèl medžioklei netinka nei religinėms apeigoms skirtas, nei prigimtinės tvarkos neatitinkantis, nei neatidèliotinam pareigu atlikimui skirtas laikas.

Bet apie tuos dalykus pakaks, nes ne apie medžioklę pasakoti, o apie dvariškių pramogas pasiūlyta šnekèti.

I vietą taip pat reikia atsižvelgti - būtent, ar tai yra asmens, ar bendruomenès, ar vieša teritorija; ar medžiojant nebus kam nors pakenkta; ar toje vietoje leidžiama medžioti, ar ji dèl savo garbingumo ir šventumo nuo tokio pobūdžio veiklos nèra apsaugota. Juk tas, kuris neprotingai ịsibrauna i̇ svetimą teritoriją i̦statymo kilpomis traukiamas atsakomybèn. O girtinas tas medžioklès būdas, kai medžiojama saikingai (ir, jei tai įmanoma, naudingai), kaip pataria komediju autorius - Nieko per daug (Terenti 166 pr. Kr.: 61). Juk ir išminčius bus pavadintas bepročiu, o teisuolis neteisingu, jei siekdamas dorybės peržengs saiko ribas (Horatii 21 pr. Kr. a.: Liber 1 VI, 15). Tačiau nèra nieko gėdingesnio, negu leisti apsijuokti žiūrovų akivaizdoje, kai nesimokęs ir neišmanydamas meno, stengiesi ji demonstruoti, panašiai kaip kad kalbètum kalba, kurios net neketini išmokti.

Bet egzistuoja ne tik nuo šios, bet ir nuo kitų, dar lengvabūdiškesnių ir malonesniu veiklu visam laikui atskirti asmenys: tie, kurie šventiesiems ordinams priklauso, ir tie, kurie vadovauja svarbiausioms administravimo įstaigoms, nes jie bus kaltinami už tai, už ką kitiems atleidžiama kaip už smulkų nusižengimą. Ir iš tiesų visada kaltesni tie, kurie niekais paverčia jau isigaliojusią sutarti, negu tie, kurie trukdo ją sudaryti. Be to, medžioklè savo vargšams klientams ne tik trukdo kilti dorybès ir tiesos laiptais, bet net ir aukščiausiems dvasininkams atima jau pasiektą laipsni. Kalbama, kad apie tai, kaip ir apie daugeli kitų dalyku, puikiai pasisakè Temistoklis: Aukštas pareigūnas privalo būti atskirtas nuo žaidyniu ir visokiu kitokiu lengvabūdišku dalyku, kad neatrodytu, jog valstybe užsiima žaidimais ir demonstruoja trūkumus, švaistydama savo orumo likučius. Bet jeigu valdantiesiems pasitaikytu išsilaisvinti nuo darbu (kas retai atsitinka), tai tiems, kurie dar yra jauni, turi būti leidžiama trumpam pamiršti oficialu oruma ir büti sau atlaidesniems, nes bręsdami jie valstybei atsilygins naudingumu. Tokie yra jo žodžiai. O kad ji išgirstu mūsų valdovai ir, atẻję $\mathfrak{i}$ 
prota, rimtus valstybės reikalus laikytų svarbesniais už savo pramogas. Juk tada visas valstybės kūnas savo sveikatos galia suklestėtų. Tada jai būtu suteikta puikiausios dermės rūšis ir ji būtu papuošta elegantišku, jai derančiu grožiu, jei kiekviena atskira dalis užimtu jai deramai skirta vieta (Horatius 1936: 87$)^{19}$ ir jei būtų tinkamas pareigu paskirstymas, o ne sumaištis. Šitai su sąlyga, jei bus vadovaujamasi geriausiu gyvenimo vedliu - prigimtimi (Ciceronis 44 pr. Kr. b.: 19). Tačiau dabar tuo, kas pridera gydytojams, užsiima amatininkai, gydytojai verčiasi amatais (Horatii 21 pr. Kr. a.: Liber 2 I, 115-16), o tarnybų vadovų ir žemesnèms pareigoms skiriami medžiotojai ar net nusikaltèliai, ir privačiu asmenų begėdystė arba dalyko neišmanymas drįsta kištis ị valstybès reikalus.

\section{Literatūra}

Ciceronis Tulli, Marcus. 44 pr. Kr. a. De Officiis. $<$ https://archive.org/details/lucancivilwarboo00lucauoft/page/86/mode/2up> [žiūrèta 202108 23]

Ciceronis Tulli, Marcus. 44 pr. Kr. b. Laevius De Amicitia. $<$ https://www.thelatinlibrary.com/cicero/amic.shtml\#19> [žiūrèta 202108 26]

Hesiodas. 2002. Teogonija. Iš senosios graikų k. vertė Audronė Kudulytè-Kairienè. Vilnius: Aidai.

Homeras. 1997. Odisèja. Iš senosios graikų k. vertè Antanas Dambrauskas. Vilnius: Vaga.

Horatii Flacci, Quintus. 21 pr. Kr. a. Epistulae. <https://www.thelatinlibrary.com/hor.html> [žiūrèta 202108 19]

Horatii Flacci, Quintus. Sermones. 30 pr. Kr. b. <https://www.thelatinlibrary.com/hor.html> [žiūrèta 202108 19]

Horatius Flaccus, Quintus. 1936. Ars Poetika. Iš lotynų k. vertė Aleksys Churginas. Kaunas.

\section{Nuorodos}

1 Mirtingasis nesupranta didybès, - panašus jis $i$ nugaištančius gyvulius (Ps 49, 21).

2 Žmogus yra lyg vejjo dvelktelëjimas, - jo dienos lyg dingstantis šešèlis (Ps 144, 4).

3 Iš pradžių i̇steigtas kaip baudžiamasis teismas Atẻnų Areopagas vèliau tapo galingu istatymų leidybos ir vykdomosios valdžios organu. Žr. Valerii Maximi Factorum et Dictorum Memorabilium Libri Novem, 2.6.4. < https://www.thelatinlibrary.com/valmax2.html > [žiūrèta 202108 23]

4 Taigi jis tuoj melagingais sparnais sudrebina ora / Ir ilijieti [tebieti] pagrobia, Tasai [Ganimedas] ir dabar tebepilsto / Gerima $i$ taures, nors ir skersakiuoja Junoné.
Juvenalis. 1983. Satyros. Iš lotynų k. vertė Aleksandra Bendoriūtè. Vilnius: Vaga.

Lucanus, Marcus Annaeus. 1962. Pharsalia. Lucan, The Civil War, with an English translation by J. D. DUFF. London: William Heinemann LTD. Ovidijus. 1979. Metamorfozés. Iš lotynų k. vertè Antanas Dambrauskas. Vilnius: Mintis.

Plinius Secundus, Caius. AD77. Naturalis Historia. $<$ https://penelope.uchicago.edu/Thayer/L/Roman/Texts/Pliny_the_Elder/8*.html $>$ [žūrèta 202108 20]

Terenti Afri, Publius. 166 pr. Kr. Andria. <https:// www.thelatinlibrary.com/ter.andria.html> [žiūrèta 202108 25]

Vergilijus. 1989. Eneida. Iš lotynų k. vertė Antanas Dambrauskas. Vilnius: Vaga.

5 Laikotarpis maždaug nuo sausio pirmos iki gegužès dvidešimt antros dienos.

6 Senovès Albanija užèmè teritoriją Rytuose nuo Kaspijos jūros.

7 Vergilijus, kuris viduramžiais buvo laikomas žiniuoniu.

8 Kušui gime Nimrodas, pirmasis galiūnas žeméje. VIEŠPATIES malone jis buvo galingas medžiotojas, dèl to ir sakoma: "Kaip Nimrodas VIEŠPATIES malone galingas medžiotojas"10. Jo karalystès pradžia buvo Babilonas, Erechas ir Akadas - miestai Šinaro krašte (Pr 10, 10).

9 Babilonas buvo auksine taure VIEŠPATIES rankoje, nugirdanti visa žeme (Jer 51, 7). 
10 Bet aukštybiu Jeruzale laisva, ir ji yra mūsu motina (Gal 4, 26).

11 Esavas buvo igudęs medžiotojas, laukus mègstąs vyras... (Pr 25, 27 ir toliau).

12 Ten yra Edomas, jo karaliai ir visi vadai, kurie, nors ir galingi, paguldyti su žuvusiais nuo kalavijo, - jie guli su neapipjaustytaisiais, su žengiančiais $i$ Duobe (Ez 32, 29-30).

13 Po to pasiusiu daug medžiotoju, kad juos sumedžiotu visuose kalnuose ir kalvose ir visu uolu urvuose (Jer 16, 16).

14 „Soranas (gr. Sōranos) Efezietis (II a. po Kr.), gr. gydytojas, vadinamosios metodikų mokyklos šalininkas..." Antikos žodynas, Vilnius: Alma littera, 1998, p. 468.

15 „Architas Tarentietis (apie 380 pr. Kr.) graikų politikas, filosofas, pitagorininkas, matematikas.
Pitagorizmo iš jo mokèsi Platonas." Antikos žodynas, Vilnius: Alma littera, 1998, p. 47.

16 Paprasčiau tariant, tikslas pateisina priemones.

17 Kai Izaokas buvo senas ir jo akys buvo taip aptemusios, kad nebegalejo matyti, jis pasišaukè savo vyresnịji sūnų ir jam tarè: „Mano sūnau!“ O šis atsiliepè: „Aš čia“. Jam tarè: „Matai, kad jau pasenau. Nežinau savo mirties dienos. Taigi imk savo ginklus - strèlinę ir lanka, išeik ị laukus ir sumedžiok man žvèrienos. Tuomet paruošk man gardų valgi, kaip aš mėgstu, ir atnešk ji man pavalgyti, idant prieš mirdamas tau suteikčiau savo sielos palaiminimą" (Pr 27, 1-4).

18 Dvasios vaisiai yra meile, džiaugsmas, taika, kantrybè, malonumas, gerumas, ištikimybè, romumas, susivaldymas (Gal 5, 22).

19 Lai vietos, jam skirtos, kiekvienas žanras žiūri.

Iš lotynų kalbos vertė prof. dr. Gintautas VYŠNIAUSKAS Klaipėdos universitetas

Versta iš Ioannis Saresberiensis episcopi Carnotensis Policratici sive De nugis curialium et vestigiis philosophorum libri 8; recognovit et prolegomenis, apparatu critico, commentario, indicibus instruxit Clemens C.I. Webb. 1909. Oxonii E Typographeo Clarendoniano <https://archive.org/details/ioannissaresberi01johnuoft/page/n13/mode/2up> [žiūrèta 202108 23] 